\title{
A new method for removing microflora from macroalgal surfaces: an important step for natural product discovery
}

\author{
Betty Kientz, Marie Thabard, Simon M. Cragg, \\ Josephine Pope and Claire Hellio* \\ School of Biological Sciences, King Henry Building, \\ Portsmouth University, Portsmouth PO1 2DY, UK, \\ e-mail: claire.hellio@port.ac.uk \\ * Corresponding author
}

\begin{abstract}
Numerous marine organisms, including macroalgae, produce bioactive compounds. As chemical extraction processes do not distinguish between compounds originating from the alga and its associated microflora, a key step immediately prior to isolation of molecules, is elimination of epibionts from the alga studied. In chemical, ecological and biotechnological contexts, a clear identification of the source organism when there are symbiotic interactions occurs is crucial. We aimed to improve understanding of specific secondary metabolite production by macroalgae through development of a methodology for removing microbial epibionts immediately prior to chemical extraction without damaging algal cell surfaces (to avoid extraction of endogenous macroalgal compounds at this stage). Various solutions were tested: non-polar solvents (dichloromethane and hexane), alcohols (methanol, ethanol and isopropanol), oxidants (sodium hypochlorite, hydrogen peroxide and iodine) and a natural product (tea tree oil) at various concentrations and contact times. Five macroalgal species were employed: Chondrus crispus, Fucus serratus, Palmaria palmata, Saccharina latissima and Ulva lactuca. Scanning electron microscopy was used to evaluate the surface integrity. The best epibiont removal rate without damaging tissue was obtained with mixtures of ethanol (40-50\%) and sodium hypochlorite (1\%). Interestingly, macroalgal moisture content influenced treatment efficacy.
\end{abstract}

Keywords: epibionts; macroalgae; microflora; natural product discovery; surface disinfection.

\section{Introduction}

In marine environments, microorganisms rapidly colonize any exposed surfaces through a very complex and highly dynamic process known as microfouling (Wahl 1989, Stoodley et al. 2002, Qian et al. 2007). Typically, $1 \mathrm{ml}$ of seawater contains $10^{1}$ to $10^{2}$ algal spores and invertebrate larvae, $10^{3}$ fungal cells and $10^{6}$ bacteria (Harder 2009). A significant proportion of these species have an absolute requirement for settlement on living or non-living surfaces where moisture is present (Characklis and Bryers 1981, Hall-Stoodley et al. 2004, Qian et al. 2007, Huang et al. 2008). Conditioned surfaces (harboring organic substances) support growth of bacterial cells, which will in turn colonize and produce a matrix of extracellular polysaccharides maintaining cells in close contact and trapping nutrients from the environment thus allowing metabolism and division under a thick protective coating (Costerton 1999, Armstrong et al. 2001, Sutherland 2001, Donlan 2002). The initial bacterial biofilm facilitates subsequent settlement and development of other organisms such as microfoulers (fungi and microalgae) and macrofoulers (macroalgae and invertebrates) (Harder 2009). In environments where competition for space is crucial, epibiosis (fouling of living surfaces) is a common phenomenon. Benthic marine macroalgae offer a particularly welcoming habitat for microfoulers due to the production of surface mucus and exudates (Sieburth 1969, Decho 2000), and to the fact that they are restricted to the photic zone where conditions for epibiont growth are optimal (De Nys et al. 1998, Steinberg and De Nys 2002). This fouling process, if not controlled, can be detrimental for the host by reducing photosynthesis, nutrient access, damaging soft tissue, increasing load imposed by basibiont weight and increased brittleness (caused by crustose epibionts) that can lead to breakage in high turbulence environments (Wahl 1989). To counteract this phenomenon, many marine organisms have developed mechanical and chemical protective mechanisms or processes to select and control the species growing in their epiflora (Wahl 1989, 2008, Wahl et al. 1998, Ralston and Swain 2009, Scardino et al. 2009), and epibiosis may then be beneficial to marine organisms. For example, Lachnit et al. (2009) demonstrated the presence of host-specific associations between algae and bacteria, suggesting that algae may control the associated bacterial community, with the bacterial biofilm conferring protection on the host alga by producing secondary metabolites (Okami 1986, Kelecom 2002, Zheng et al. 2005, Mayer et al. 2009). The epiphytic microbial community may produce large quantities of secondary metabolites (Prieur et al. 1993, Jensen and Fenical 1996, Bernan et al. 1997, Boyd et al. 1999), which have been proven to regulate the impact of abiotic and biotic stressors such as UV radiation, desiccation, pathogens, parasites, consumers and macrofoulers (Wahl 2008). Moreover, several molecules found in macroalgae possess structures resembling those of molecules recently purified from bacteria isolated the surfaces of their hosts; some substances isolated from macroalgae are indeed metabolized by their associated microorganisms (Zheng et al. 2005).

Chemical defense strategies in marine organisms are under extensive investigation, and over the past 40 years marine biotechnological research has led to the discovery of many 
novel compounds with interesting bioactivities attributable to their unique chemical structures (Clare 1996, 1998, Faulkner 2001, Fusetani 2004, Blunt et al. 2009, Hellio et al. 2009, Molinski et al. 2009). The first step in the search for new compounds is screening of fresh material sampled directly from the marine environment. Although removal of macroepibionts can be done manually, the presence of microepibionts can be problematic when looking for new compounds. Indeed, after chemical extraction and purification, it is impossible to determine whether the new compound detected originates from the epibiont or the basibiont. Identification of the source organism is thus crucial both from industrial and ecological standpoints. To develop new, "green', sustainable production of marine natural products by cultivation of marine organisms rather than by chemical synthesis, it is essential to determine whether the producers are macroalgae or their eiphytic microorganisms, as the outcome will dictate the manner of production. Furthermore, most marine sessile organisms will not produce a variety of interesting defense metabolites in the absence of an associated microflora (Wahl 2008). It is thus very important to design methodologies that (i) allow macroalgae to grow with their naturally associated microflora to ensure production of active metabolites and (ii) incorporate a procedure (to be used immediately before chemical extraction) to separate microbiologically produced compounds from those produced by their seaweed hosts.

If sustainable production of active compounds by macroalgal cultivation is planned, elimination of microorganisms from algal surfaces is an important step before proceeding to basiobiont chemical extraction. Moreover, progress in the field of chemical ecology will require this first technical step to ensure that interaction effects are attributed to the correct species among the suite of taxa occupying native habitats. Despite the importance of the topic, few publications have addressed the issue of disinfection of macroalgal surfaces prior to metabolite extraction (Fu et al. 1999, Schulz et al. 2008). Nevertheless, development of axenic cultures has focused on these aspects (Gusev et al. 1984, 1987, Xue-wu and Gordon 1987, Lawlor et al. 1991, Garcia-Jiménez et al. 1998, Choi et al. 2002, Rorrer and Cheney 2004, Harrison and Berges 2005) and it has been shown that disinfection of macroalgae is difficult as they lack a thick surface cuticle and can be easily damaged (Reddy et al. 2008, Baweja et al. 2009). Methods developed for aquaculture purposes often combine physical surface cleaning of macroepiphytes (using brushes, razors, sonication or osmotic shocks) (Xue-wu and Gordon 1987) and chemical treatment for microflora elimination (surfactant, alcohols, oxidizing agents, iodine and antibiotics) (Baweja et al. 2009). Harrison and Berges (2005) published protocols based on the use of antibiotics. Various techniques have been developed in which algae are submerged in different bacterial disinfectants including ethanol (Gusev et al. 1987, Lawlor et al. 1991, Schulz et al. 1998) and sodium hypochlorite (Garcia-Jiménez et al. 1998). Lawlor et al. (1991) demonstrated that a treatment with $70 \%$ ethanol for $30 \mathrm{~s}$ combined with $30 \mathrm{~min}$ in deionized water was efficient in producing axenic tissue cultures from Ecklonia radiata (C. Agardh) J. Agardh (Phaeophyta). Similarly,
Gusev et al. (1984, 1987) employed $70 \%$ ethanol and $1 \%$ chlorhexidine bigluconate for $15 \mathrm{~min}$ to produce axenic marine algae. To develop a non-phytotoxic sterilizing treatment for Dictyotales (Phaeophyta), Aguirre-Lipperheide and Evans (1993) brushed explants and incubated them in betadine $(0.50 \%)$ for $5 \mathrm{~min}$, followed by immersion in an antibiotic mixture (kanamycin, neomycin and penicillin $\mathrm{G}$ ) for $48 \mathrm{~h}$. Betadine was also used, followed by $80 \%$ ethanol treatment, for Undaria pinnatifida (Harvey) Suringar (Phaeophyceae) callus regeneration (Kawashima and Tokuda 1993). Hypochlorite for 30-60 s was employed on a laminarian (Phaeophyta) (Fries 1980). Nevertheless, these agents can easily damage delicate tissue (Baweja et al. 2009). Mixtures of antibiotics can be employed, but these usually last for 2-7 days (Bradley et al. 1988, Xuewu and Kloareg 1992, Garcia-Jiménez et al. 1998, Choi et al. 2002) and introduce molecules that could be wrongly sourced to the algae. Diverse agents and methods are employed for tissue sterilization, but no standardized protocol has been published. The main limits of the treatments used to date are that there is no evaluation of algal surface deterioration attributable to disinfection. The efficiency of microfloral removal is often evaluated using a unique seawater-based culture medium that is not suitable for growing the full range of microorganisms present on the basibiont surface.

In this study, we evaluated the efficiency of various biocidal agents in macroalgal microepibiotal elimination, with the aim of developing a simple, non-aggressive and reliable protocol to be used immediately prior to chemical extraction for natural product discovery (with correct identification of the organism responsible for production of the metabolites). For this purpose, non-polar agents (dichloromethane and hexane), alcohols (methanol, ethanol and isopropanol), oxidants (iodine, sodium hypochlorite and hydrogen peroxide) and a natural product (tea tree oil) were employed. Assessments of treatment efficacy were performed using intertidal macroalgae from several higher taxa: Chlorophyta (Ulva lactuca Linnaeus), Phaeophyceae [Fucus serratus Linnaeus and Saccharina latissima (Linnaeus) C.E. Lane, C. Mayes, Druehl et G.W. Saunders] and Rhodophyta [Chondrus crispus Stackhouse and Palmaria palmata (Linnaeus) Weber et Mohr] by imprinting treated and non-treated frond fragments (Schulz et al. 2008) on a wide range of solid media. This enabled detection of surviving epibiotic bacteria, microalgae and fungi. Basibiont cell lysis was also further investigated by direct observation of algal surface by scanning electron microscopy (SEM) because solvent treatment may damage the surfaces of host algal cells (De Nys et al. 1998).

\section{Materials and methods}

\section{Macroalgal models}

Macroalgae were collected from the intertidal zone at Portsmouth, UK (50 46 $\left.41^{\prime} \mathrm{N}, 1^{\circ} 5^{\prime} 20^{\prime \prime} \mathrm{W}\right)$ between February and June. Collections were performed wearing plastic gloves to avoid microbial contamination of specimens (Gledhill et al. 1998). Samples were transported to the laboratory in

\section{Q1:}

Please

supply year

for date of

collection in

the following sentence:

'Macroalgae

were

collected

from the

intertidal

zone at

Portsmouth,

UK $\left(50^{\circ} 46^{\prime}\right.$

$41^{\prime \prime} \mathrm{N}, 1^{\circ} 5^{\prime}$

$20^{\prime \prime} \mathrm{W}$ )

between

February and

June ????' 
plastic bags and processed immediately to minimize contamination (Lawlor et al. 1991). The first set of experiments was conducted using F. serratus (Phaeophyceae, Fucales, Fucaceae), which is commonly found in the North Atlantic, and P. palmata (Rhodophyceae, Palmariales, Palmariaceae), which occurs on northern coasts of both the Atlantic and Pacific oceans. Experiments were then extended to three more species: C. crispus (Rhodophyceae, Gigartinales, Gigartinaceae) distributed from Iceland to West Africa and the northeastern coast of North America, S. latissima (Phaeophyceae, Laminariales, Laminariaceae) widely distributed on the North Atlantic coast of Europe and the Pacific coasts of America and Japan and U. lactuca Linnaeus (Chlorophyceae, Ulvophyceae, Ulvaceae), a ubiquitous species found on most exposed rocky shores (although under-recorded in Ireland).

\section{Culture media used for the growth of microorganisms}

Culture media were purchased from Difco Laboratory (West Molesey, UK) and Oxoid (Basingstoke, UK). They were chosen to allow the detection of a wide range of microorganisms (Table 1). Agar $\left(15 \mathrm{~g} \mathrm{l}^{-1}\right)$ was added in a broth for solid medium formulation.

To prevent bacterial growth on fungi and microalgal media, segments used were bathed for $24 \mathrm{~h}$ in an antibiotic bath of $5 \mathrm{mg} \mathrm{ml}^{-1}$ of penicillin (against Gram positive bacteria) and $1.6 \mathrm{mg} \mathrm{ml}^{-1}$ of streptomycin (against Gram negative bacteria).

\section{Agents tested}

All chemicals were purchased from Fisher (Loughborough, UK). Ethanol, methanol and isopropanol were diluted with distilled water to obtain six concentrations $(10 \%, 20 \%, 40 \%$, $50 \%, 60 \%$ and $80 \%$ ) (Table 2). Alcohols act on microorganisms by lipid dissolution and protein denaturation. The biocidal effect increases with molecular weight, thus isopropanol has a higher potency than ethanol (Wilson et al. 1964). Non-polar solvents such as hexane and dichloromethane were not diluted. Oxidizing agents were tested at $1 \%$ and $3 \%$ for sodium hypochlorite $(\mathrm{NaOCl}), 4.5 \%$ for iodine in $2 \%$ potassium iodide and $3 \%$ for hydrogen peroxide $\left(\mathrm{H}_{2} \mathrm{O}_{2}\right)$. The main biocidal property of oxidizing agents is oxidation of cell constituents by liberating hydroxyl radicals, which leads to cell lysis. These agents possess bactericidal activity and also interesting sporicidal action. Tea tree oil was tested at $1 \%$ in $70 \%$ ethanol. Chemicals were tested at five immersion times: 10, 30, $60 \mathrm{~s}, 5 \mathrm{~min}$ and $10 \mathrm{~min}$.

Combined treatments were also performed, but at shorter immersion times: 10, 30 and 60 s. Solutions of ethanol (40-60\%) mixed with oxidants such as sodium hypochlorite $(1 \%)$ or hydrogen peroxide $(3 \%)$ were investigated.

\section{Method of surface sterilization}

After collection, macroalgal fronds were bathed twice for $5 \mathrm{~min}$ in sterile artificial SW (Instant Ocean ${ }^{\odot}$, Hyde, UK) prior to immersion in the experimental treatments, to remove loosely attached macrobionts. Fragments of fronds were then excised using a sterilized cork borer (size no. 18). The effectiveness of surface disinfection was tested by imprinting the treated frond segments on solid media in duplicate (Table 2) (Schulz et al. 1998). Six fronds segments were tested on each treatment. Duplicates of non-treated fragments were used as controls. All the experiments were done using two batches of algae. As the results from the two batches were not significantly different, they have been pooled.

Table 1 Classes of microorganisms detected on solid culture media prepared in freshwater (FW) or seawater (SW).

\begin{tabular}{|c|c|c|c|}
\hline Microfoulers & Medium $^{a}$ name & & Microorganisms detected \\
\hline \multirow[t]{6}{*}{ Bacteria } & Nutrient broth $\mathrm{n} 2^{\mathrm{b}}$ & FW & Wide variety of soil microorganisms \\
\hline & Marine broth $2216^{\mathrm{c}}$ & SW & Marine bacteria \\
\hline & Brain Heart infusion $^{\mathrm{d}}$ & SW & $\begin{array}{l}\text { Wide variety of marine and soil microorganisms: fastidious and } \\
\text { non-fastidious, aerobic and anaerobic bacteria }\end{array}$ \\
\hline & MacConkey broth ${ }^{\mathrm{e}}$ & FW & Lactose-fermenting bacteria \\
\hline & Mueller-Hinton $^{\mathrm{b}}$ & SW & Fastidious and non-fastidious microorganisms \\
\hline & $X_{L} D^{f}$ & FW & $\begin{array}{l}\text { Non-fermenting xylose, lactose, sucrose bacteria (red coloration) } \\
\text { such as enteric pathogens }\end{array}$ \\
\hline \multirow[t]{4}{*}{ Fungi } & Sabouraud dextrose ${ }^{\mathrm{b}}$ & SW & Marine yeast and filamentous fungi \\
\hline & Malt extract ${ }^{\mathrm{d}}$ & SW & Marine heat-resistant filamentous fungi \\
\hline & Potato dextrose ${ }^{\mathrm{b}}$ & FW & Yeast and filamentous fungi \\
\hline & Czapek Dox ${ }^{\mathrm{d}}$ & FW & Soil fungi \\
\hline \multirow[t]{2}{*}{ Microalgae } & $\mathrm{f} / 2^{\mathrm{g}}$ & SW & Marine microalgae \\
\hline & $\mathrm{f} / 2+\mathrm{Si}^{\mathrm{h}}$ & SW & Marine microalgae and diatoms \\
\hline
\end{tabular}

${ }^{\mathrm{a}} 15 \mathrm{~g} \mathrm{l}^{-1}$ of agar.

${ }^{\mathrm{b}}$ Atlas (2004).

'Zobell (1941).

${ }^{\mathrm{d}}$ Atlas and Parks (1993).

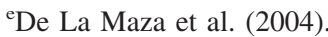

${ }^{\mathrm{f}} \mathrm{Nye}$ et al. (2002).

${ }^{\mathrm{g}}$ Guillard and Ryther (1962).

${ }^{\mathrm{h}}$ Harrison and Berges (2005). 
Table 2 Details of assessments used to assess surface disinfection of macroalgae.

\begin{tabular}{|c|c|c|c|c|}
\hline Agents tested & & Concentrations & Immersion times & Culture media \\
\hline \multicolumn{5}{|l|}{ Single treatments } \\
\hline \multirow[t]{2}{*}{ Non-polar solvents } & Hexane & $100 \%$ & & \multirow{4}{*}{$\begin{array}{l}\text { Bacteria: Marine broth, Nutrient broth, } \\
\text { Brain Heart infusion. } \\
\text { Fungi: Sabouraud } \\
\text { dextrose, malt extract, } \\
\text { potato dextrose, } \\
\text { Czapek Dox. }\end{array}$} \\
\hline & Dichloromethane & $100 \%$ & & \\
\hline Alcohols & $\begin{array}{l}\text { Methanol } \\
\text { Ethanol } \\
\text { Isopropanol }\end{array}$ & $\begin{array}{l}10 \%, 20 \%, 40 \% \\
50 \%, 60 \% \text { and } 80 \%\end{array}$ & & \\
\hline Oxidants & $\begin{array}{l}\text { Hydrogen peroxide } \\
\text { Iodine } \\
\text { Sodium hypochlorite }\end{array}$ & $\begin{array}{l}1 \% \\
4.5 \% \\
1 \%, 3 \%\end{array}$ & $\begin{array}{l}10,30,60 \mathrm{~s} \\
\text { and } 5,10 \mathrm{~min}\end{array}$ & \\
\hline Biological agent & Tea tee oil & $1 \%$ & & Microalgae: $\mathrm{f} / 2, \mathrm{f} / 2+\mathrm{Si}$ \\
\hline \multicolumn{5}{|l|}{ Mixed treatments } \\
\hline Ethanol and oxidants & $\begin{array}{l}\text { Ethanol and } \\
\text { sodium hypochlorite } \\
\text { Ethanol and } \\
\text { hydrogen peroxide }\end{array}$ & $\begin{array}{l}50 \%+ \\
1 \% \\
50 \%+ \\
30 \% \\
\end{array}$ & $10,30,60 \mathrm{~s}$ & $\begin{array}{l}\text { Supplementary } \\
\text { bacterial media: } \\
\text { Mueller-Hinton, XLD, } \\
\text { MacConkey broth }\end{array}$ \\
\hline
\end{tabular}

Data were collected after $48 \mathrm{~h}$ incubation at $28^{\circ} \mathrm{C}$ for bacteria, a minimum of 6 days at $25^{\circ} \mathrm{C}$ for fungi and 12 days under constant illumination for microalgae. The presence of microbial growth was coded as follows: "+," when the growth was similar to that on the control plates; " $\sim$, a slight elimination of microorganism with $<10$ colonies; " a total elimination of the microorganisms. For the mixed treatment tests, colonies were counted and recorded as colony-forming units (CFU).

\section{Observations of algal cell integrity}

Sample preparation was performed following the procedure of Callow et al. (1978): fragments of algal tissue were first fixed for $2 \mathrm{~h}$ in $5 \%$ glutaraldehyde in $0.1 \mathrm{M}$ cacodylate buffer containing $0.25 \mathrm{M}$ sucrose at $\mathrm{pH}$ 7. Dehydration was then conducted using a graded ethanol series $(30 \%, 50 \%, 70 \%$, $90 \%$ and $100 \%$ ) with an incubation time of $20 \mathrm{~min}$ for each step. The specimens were then transferred into hexamethyldisilazane (HMDS), which was allowed to evaporate overnight. Specimens were mounted on carbon tab stubs and sputter coated using a gold/palladium alloy target. Samples were examined with a JEOL 6060VL SEM (sputter coater, model E50000; Welwyn Garden City, UK) operating in secondary electron mode. Presence of cracks and crevices was determined by comparison of treatments with SEM images of control algal surface cells. The degree of microbial colonization of the algal surfaces (control and experimental) was determined by visual evaluation of three randomly selected fields of view at magnifications of $1500 \times$ or $2000 \times$.

\section{Moisture content determination}

The sterilizing action of some agents such as ethanol (for example) depends on penetration, which is affected by surface moisture content (Wilson et al. 1964). In our final adaptation of treatments and because of variation in first results between macroalgal species, we evaluated moisture content. Fresh material was collected and gently pressed between sheets of absorbent paper to remove excess moisture.
Macroalgal tissue was then dried for $48 \mathrm{~h}$ at $70^{\circ} \mathrm{C}$ in an oven. Measurements of wet and dry weights were performed to determine moisture content of each species. Measurements were done using six batches of algae and results are presented as the average moisture contents of the replicates.

\section{Results}

Colonies of marine bacteria were observed on culture medium plates earlier than those of soil bacteria (usually within $24 \mathrm{~h}$ of incubation as opposed to within $48 \mathrm{~h}$ of incubation) (data not shown), demonstrating that marine bacteria grew faster and were less sensitive to sterilizing treatment. No microalgae developed on plates, although diatom cells were observed on $P$. palmata by SEM. Selective solid media permitted the isolation of marine fungi and thus an estimation of the fungicide potency of treatments. The full extent of the fungal diversity may not have been evaluated due to rapid expansion on plate of some specific fungal strains in the preliminary assessment of efficiency. Thus, the data presented within here refer principally to bacterial growth (as bacteria were the major component of the microflora). Algal tissue discoloration occurred after some treatments. This may indicate cell disruption and/or metabolite extraction (data not shown). Therefore, any treatments causing discoloring were discarded for the final selection of the best protocol for sterilization.

\section{Non-polar solvents}

The non-polar solvents hexane and dichloromethane (100\%) did not discolor algal tissue. However, they were not efficient and bacterial growth was abundant on all media tested as well as on controls after these treatments (Table 3).

\section{Alcohols}

Tissue discoloration of both $P$. palmata and $F$. serratus occurred rapidly (within $60 \mathrm{~s}$ of dipping) after immersion in 
$60 \%$ ethanol, $40 \%$ isopropanol and $80 \%$ methanol (Table 3). Methanol and isopropanol were not effective disinfectants, but ethanol reduced cultivable bacteria on the media used at some concentrations and dipping times (Table 3). Short exposure times $(\leq 60 \mathrm{~s})$ in alcohol were more efficient at removing epibiota than longer immersion contact times (5 and $10 \mathrm{~min}$ ) while not causing discoloration. Results showed that $50 \%$ and $40 \%$ ethanol on F. serratus and $60 \%$ on $P$. palmata (both species treated for short contact times, $\leq 60 \mathrm{~s}$ ) had the highest activity. These concentrations of alcohol were threshold levels above which tissue discoloration occurred.

To better characterize the efficiency of ethanol, additional treatment durations $(1,2,3,4$ and $5 \mathrm{~min})$ were tested using $40 \%$ and $60 \%$ ethanol, respectively, for $F$. serratus and P. palmata and $50 \%$ for both species (Figure 1). Discoloration occurred when P. palmata was exposed to $60 \%$ or $50 \%$ ethanol for 2 min or more (Figure 1A, B), but only after 3 min or more in F. serratus dipped in $40 \%$ or $50 \%$ ethanol (Figure 1C, D). The best solvent for bacterial removal was $50 \%$ ethanol (1 or $2 \mathrm{~min}$ ) for $F$. serratus and $60 \%$ ethanol (1 min) for P. palmata.

\section{Oxidants}

Aqueous iodine $(4.5 \%)$ caused staining of the fronds even with short immersion times. With hydrogen peroxide treatments, a slight diminution of microflora was observed at $3 \%$ $(\geq 30 \mathrm{~s})$ in the case of $P$. palmata but resulted in frond discoloration; iodine was not efficient on F. serratus. Removal using $3 \% \mathrm{NaOCl}$ without frond bleaching was efficient (30 s) on F. serratus, as was treatment for $60 \mathrm{~s}$ in $1 \%$ bleach; treatment of $P$. palmata in $1 \%$ bleach $(30 \mathrm{~s})$ removed colonies (Table 3).

\section{Natural product}

Results showed that $70 \%$ tea tree oil in ethanol caused a decrease in number of bacteria colonies without discoloration of P. palmata following $30 \mathrm{~s}$ immersion, but was not effective in removing microorganisms without discoloring fronds of $F$. serratus (Table 3).

\section{Mixed treatments}

To enhance microorganism removal and reduce tissue discoloration, mixed treatments using the most effective alcohol and oxidizing agents (50\% ethanol and 1\% sodium hypochlorite) were tested at shorter exposure times (10, 30 and $60 \mathrm{~s}$ ). The ethanol and hydrogen peroxide mix quickly discolored algal tissues. Frond immersion for $30 \mathrm{~s}$ in $50 \%$ ethanol with $1 \% \mathrm{NaOCl}$ was effective in removing bacteria, microalgae and fungi on P. palmata (Figure 2B), but in the case of $F$. serratus, fungi grew following this treatment (data not shown). Immersion in a mix of $40 \%$ ethanol with $1 \%$ $\mathrm{NaOCl}$ for $60 \mathrm{~s}$ was effective on $F$. serratus (Figure 2C).

The most efficient treatments were thus $40 \%$ ethanol and $1 \% \mathrm{NaOCl}(60 \mathrm{~s})$ for $\mathrm{F}$. serratus and $50 \%$ ethanol and $1 \%$ 

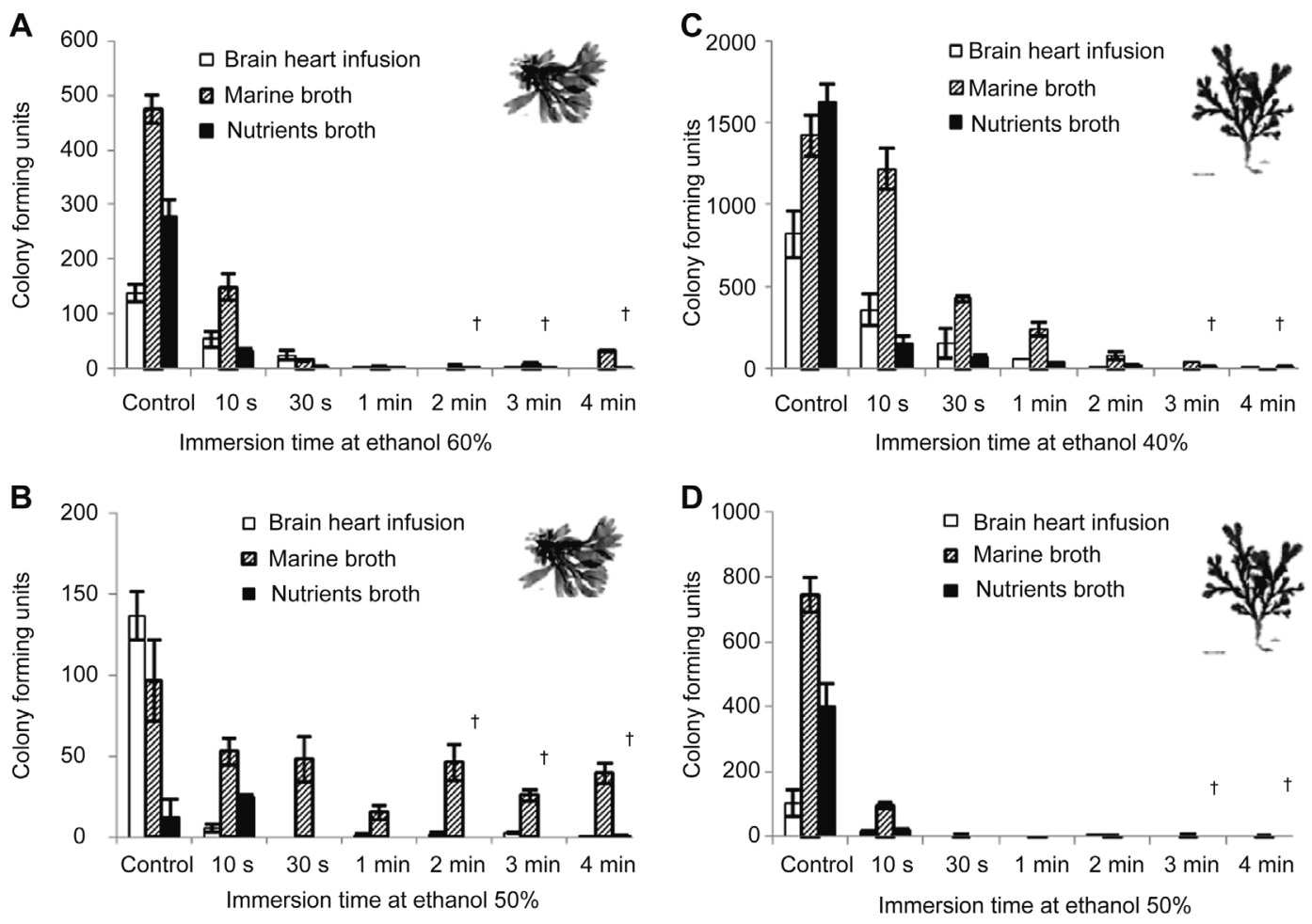

Q2:

The legend is incomplete. Please supply full text

Figure 1 Bacterial growth on macroalgal surfaces after single treatments in $60 \%$ ethanol (A) and 50\% ethanol (B) on Palmaria palmata and in $40 \%$ ethanol (C) or $50 \%$ ethanol (D) on Fucus serratus as a function of immersion time and evaluated on Brain heart agar, Marine agar and Nutrient agar.
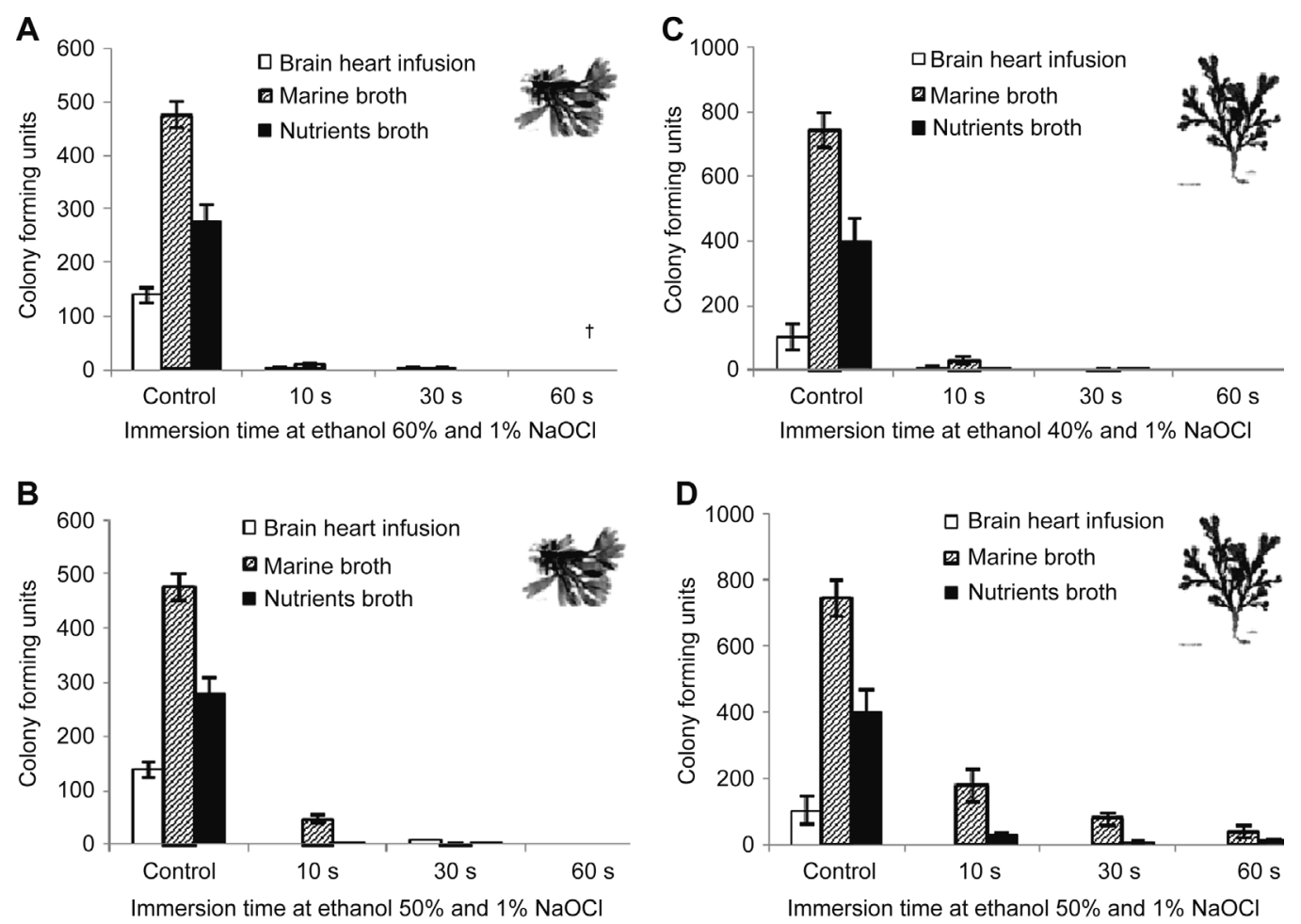

Figure 2 Bacterial growth on macroalgae surface after mixed treatments in $60 \%$ ethanol (A) or $50 \%$ ethanol (B) with $1 \% \mathrm{NaOCl}$ on Palmaria palmata and $40 \%$ ethanol (C) or $50 \%$ ethanol (D) with $1 \% \mathrm{NaOCl}$ on Fucus serratus as a function of immersion time and evaluated on Brain Heart agar, Marine agar and Nutrient agar media. Values are mean number of CFU \pm standard deviation ( $\mathrm{n}=12$ ). ('Tissue discoloration.) 


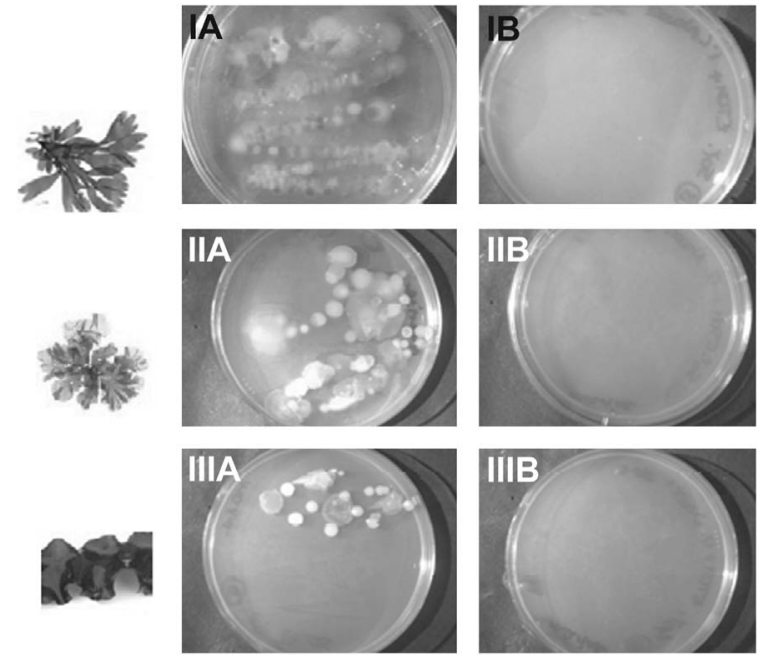

Figure 3 Microbial growth on marine agar plates.

Without treatment (A) and treated with $50 \%$ ethanol with $1 \%$ $\mathrm{NaOCl}$ for $30 \mathrm{~s}$ (B) on Palmaria palmata (I), Ulva lactuca (II) and Saccharina latissima (III).

$\mathrm{NaOCl}(30 \mathrm{~s})$ for $P$. palmata. No cells lysis was observed in these treatment combinations.

\section{Additionally tested macroalgae}

Additional experiments were run using C. crispus, S. latissima and $U$. lactuca. Tests were performed with the two more effective treatments, namely $50 \%$ and $40 \%$ ethanol together with $1 \% \mathrm{NaOCl}$. Images of marine agar plates from the pool of macroalgae tested are displayed Figures 3 and 4. Exposure to $50 \%$ ethanol with $1 \% \mathrm{NaOCl}(30 \mathrm{~s})$ eliminated marine bacteria on P. palmata, S. latissima and U. lactuca (Figure 3B), but this treatment on F. serratus and C. crispus left, respectively, six and three colonies (Figure 4B). Using $40 \%$ ethanol with $1 \% \mathrm{NaOCl}(60 \mathrm{~s})$ (Figure 4D) completely eliminated bacterial growth on marine media. In these experiments, no growth of microalgae or marine fungi was observed.

\section{Macroalgal moisture content}

The moisture contents of the five macroalgae studied are depicted in Figure 5.

\section{Observation of macroalgal surfaces}

Examination of algal fragments that had not been treated with the test solutions revealed the presence of a microflora on the surface of all macroalgae species examined and no cracks or crevices (Figure 6A). We used 50\% ethanol with $1 \% \mathrm{NaOCl}(30 \mathrm{~s})$ on P. palmata, S. latissima and U. lactuca and $40 \%$ ethanol with $1 \% \mathrm{NaOCl}(60 \mathrm{~s})$ on $C$. crispus and $F$. serratus. With these treatments, there was a diminution of microflora abundances, but a few microorganisms were still present on U. lactuca (Figure 6B, I) and S. latissima (Figure $6 \mathrm{~B}$, II) surfaces. No microflora was seen on the surface of treated $P$. palmata (Figure 6B, III), although cells seemed dehydrated. High abundances of microorganisms were observed on both $F$. serratus (Figure 6B, IV) and $C$. crispus (Figure 6A, V) controls. Specific treatment of $40 \%$ ethanol with $1 \% \mathrm{NaOCl}$ achieved biofilm reduction, in particular with respect to fungal colonization, but complete elimination did not occur on $F$. serratus (Figure 6B, IV) or $C$. crispus (Figure 6B, V). No crevices were observed in treatments, except in the case of S. latissima (Figure 6B, II).

\section{Discussion and conclusion}

The potential of macroalgae for producing novel active metabolites has been exploited for 40 years (Baker 1984, Renn 1990, Faulkner 1993, Paul and Puglisi 2004). Marine organisms mediate the colonization of prokaryotes and eukaryotes on their surfaces by the production of chemical cues. However, information on the nature, distribution and effects of these cues on the demography of colonizers is scarce (Steinberg et al. 2002). Recently, metabolites from epibiotic microorganisms were shown to have biological activity, and several studies have attributed the observed effects of molecules isolated from macroalgae to their epibionts (Haygood
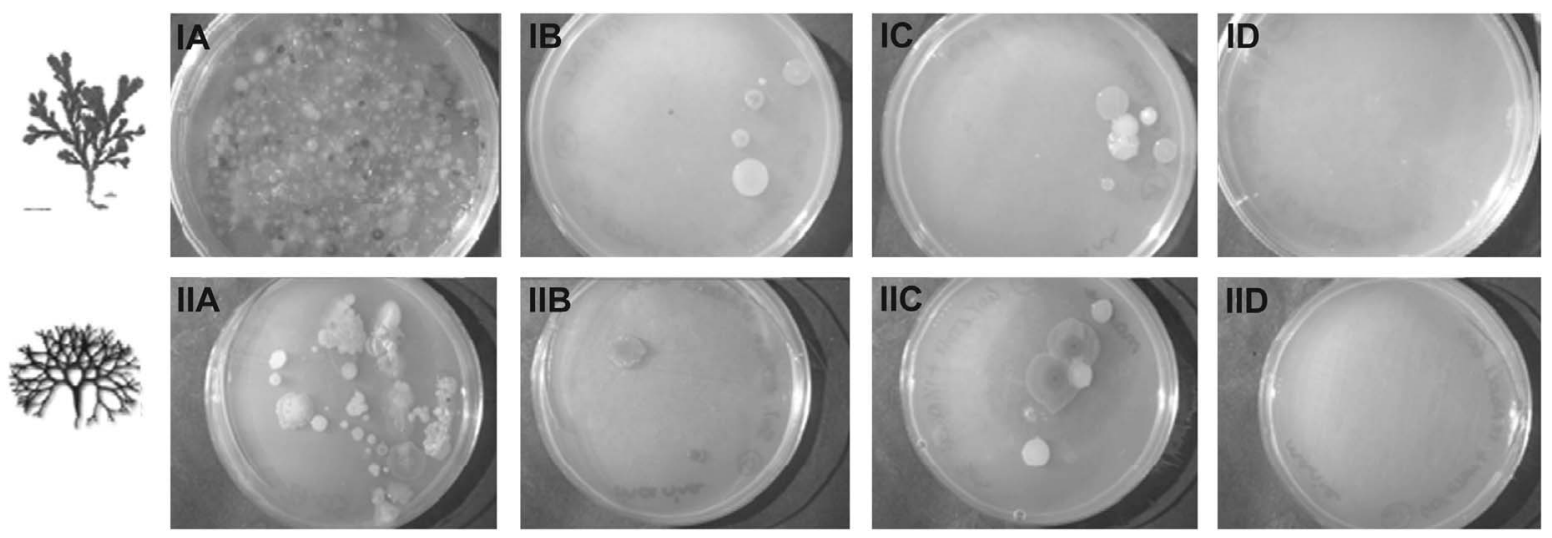

Figure 4 Microbial growth on marine agar plates.

Without treatment (A) and treated in $50 \%$ ethanol with $1 \% \mathrm{NaOCl}$ for $30 \mathrm{~s} \mathrm{(B)} 40 \%$ ethanol with $1 \% \mathrm{NaOCl}$ for $30 \mathrm{~s}$ (C), and $40 \%$ ethanol with $\mathrm{NaOCl} 1 \%$ for $60 \mathrm{~s}$ (D) on Fucus serratus (I) and Chondrus crispus (II). 


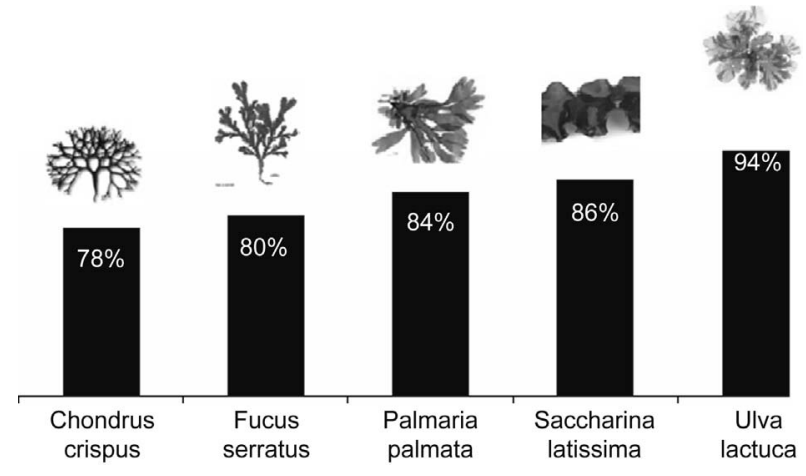

Figure 5 Moisture contents of macroalgae tested.

et al. 1999, Kelecom 2002, Proksch et al. 2002, Mérour 2004, Anand et al. 2006). A major concern in chemical ecology, as well as research into marine natural products, is to accurately determine the source organisms. Implementation of a standardized protocol is thus an important step in molecule isolation from macroalgae. This study was a comparison of treatments and the elucidation of factors affecting surface sterilizing methods for macroalgae.

Our work focused on microorganisms associated with macroalgae, among which were bacteria, fungi and microalgae. These organisms were cultivated using agar plates and several types of media to undertake a broad screening. In addition, samples were observed under SEM. The evaluation of treatment efficiency used was different from the tissue imprinting method (Schulz et al. 1998) or direct SEM observation. Indeed, some bacteria did not grow on the media used, but bacteria were observed under SEM of the host algal surfaces. This is not surprising as it is known that only $1 \%$ of bacteria can be cultivated on agar plates (Colwell and Grimes 2000, Haglund et al. 2002); therefore, SEM observation allowed for a better determination of microorganisms present on the surface. SEM is also a useful tool for observing cell lysis caused by surface disinfection.

Differences in our ability to establish cultures were observed among the three types of organisms. Bacteria and fungi grew on agar plates but microalgae did not. However, SEM images showed the presence of microalgae on macroalgal surfaces, demonstrating the slow process of microalgal growth in the laboratory as well as the difficulty of isolating them on solid media. Microalgal proliferation is also controlled by natural anti-microalgal compounds from some macroalgae such as C. crispus (Rosell and Srivastava 1987). Microalgae are less resistant than bacteria, bacterial spores and fungi (Donnell 2007) and, in theory, treatments removing bacteria should remove microalgal cells.

Fungal growth during the preliminary assessment experiments was difficult to determine owing to rapid expansion of a specific fungal species that may have stopped and/or masked the growth of others. Macroalga-associated fungi represent one-third of higher marine fungi, and ascomycetes are the most commonly observed. They are found principally on Rhodophyta and Phaeophyceae, but infrequently on Chlorophyta (Kohlmeyer and Volkmann-Kohlmeyer 2003).
Marine epiphytic and endophytic fungi are very important producers of bioactive marine natural products (Jones 2008, Hellio et al. 2009). To develop a working protocol, it is essential to prove the efficiency of the treatment for their removal. Very few fungi were detected on $U$. lactuca. There were high levels of colonization on F. serratus and some of the microbes penetrated through the algal surface, demonstrating their endosymbiotic capabilities. However, one of the limitations of this study is that we were able only to observe and comment on the potential inhibition of epiphytic species. It is presently impossible to remove endophytes without lysis of host cells. Endophytic fungi grow within macroalgae such as $F$. serratus (Zuccaro et al. 2007).

Marine bacteria were harder to remove than soil bacteria. This can be explained by the fact that marine bacteria are the major primary colonizers in marine environments and that their biodiversity is much higher than that of soil bacteria in coastal zones. As a consequence, it is more difficult to find a single treatment that can totally remove them. Moreover, as major primary colonizers, they usually occur deeper in the biofilm and are thus more protected (Davey and O'Toole 2000).

This study showed that the use of concentrated solvents leads to discoloration or bleaching of the fronds, which may be related to macroalgal tissue degradation and thus to loss of algal metabolites prior to the extraction process. Therefore, these solvents have to be ruled out as potential surface disinfectants. Iodine stained $P$. palmata tissue, which implies that molecules of iodine were present on the algal surface and might thus occur in subsequent extractions, as may molecules of essential oil. These treatments were ruled out of the final protocol. De Nys et al. (1998) demonstrated that use of hexane for extraction during immersion times of 10-30 s induced no cell lysis in Delisea pulchra Greville (Montagne) and Laurencia obtusa (Hudson) Lamouroux, but allowed extraction of surface molecules. However, they found evidence of cell lysis when using methanol, ethyl acetate, diethyl ether and dichloromethane at $100 \%$ concentrations (10-60 s contact times). This means that none of these combinations of solvents and concentration may be used for the purpose of surface disinfection without bioactive metabolite extraction. Our results complement the study of De Nys et al. (1998) and showed no sign of cell lysis while using methanol on $P$. palmata; however, discoloration was observed. To extract lipophylic molecules, previous studies have used non-polar solvents such as hexane (De Nys et al. 1998); however, we showed that associated microorganisms were not removed with this solvent. Extracellular polymeric substances (EPSs), the main components of biofilm, are highly hydrated because they are able to incorporate large amounts of water into their structure by hydrogen bonding and are thus mainly hydrophilic (Donlan 2002). This property allows water and nutrient circulation within the biofilm. The lack of sterilizing power with hexane and dichloromethane could be explained by a weak penetration of these non-polar solvents. Nevertheless, a few EPSs also possess a hydrophobic region (Sutherland 2001). Consequently, hydrophilicity cannot explain the generally limited sterilizing effect of non-polar agents. 


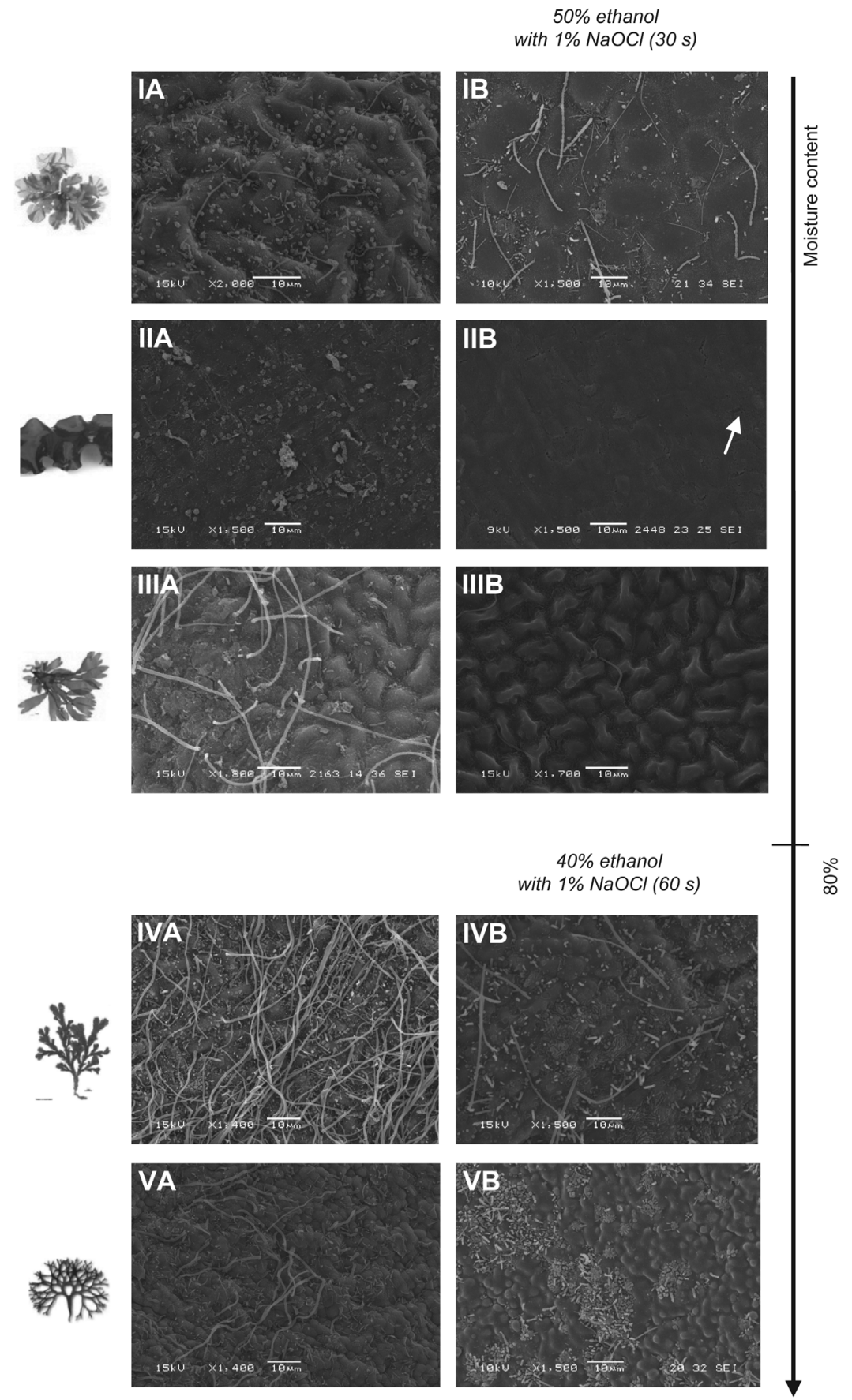

Figure 6 Epibiont communities on macroalgal surfaces observed by scanning electron microscopy and presence of crevices (indicated by an arrow).

Without treatment (A) and with effective treatment (B) in $50 \%$ ethanol with $1 \% \mathrm{NaOCl}$ for $30 \mathrm{~s}$ for Ulva Lactuca (I), Saccharina latissima (II) and Palmaria palmata (III) and $40 \%$ ethanol with $1 \% \mathrm{NaOCl}$ for $60 \mathrm{~s}$ for Fucus serratus (IV) and Chondrus crispus (V). Scale bars=10 $\mu \mathrm{m}$.

Organic and inorganic components of biofilms may neutralize activities of some biocides. Enzymes liberated within biofilms, such as peroxidase or catalase, reduce the biocidal efficacy of oxidant agents such as hydrogen peroxide (Vilter et al. 1983, Jordan et al. 1991). For example, iodoperoxidases are found on Pelvetia canaliculata (Linnaeus) Decaisne et Thuret (Pheaophycae) (Almeida et al. 2000). Haloperoxi- dases are also present in brown macroalgae (Leblanc et al. 2006). These may decrease hydrogen peroxide efficiency by reacting with hydrogen radicals. This is consistent with the present study, which demonstrated that hydrogen peroxide is not efficient against $F$. serratus biofilm. According to previous studies, marine fungi can also produce peroxidases (Debashish et al. 2005). The fungal epiphyte complement 
was high on $F$. serratus. In comparison, the P. palmata fungal community was smaller and the hydrogen peroxide treatment more effective. Sodium hypochlorite alone was efficient at high (3\%) concentration, but with discoloration. Debeer et al. (1994) also reported biocidal effect of $\mathrm{NaOCl}$ and detected a penetration of only $20 \%$ of sodium hypochlorite into microbial biofilm depending on heterogeneity and biomass of cells in the matrix. Treatment of cells included in biofilm thus needs a higher concentration than for planktonic organisms due to the protective effect of the biofilm matrix (Debeer et al. 1994).

Concentrations of alcohols higher than $80 \%$, even for short times $(<30 \mathrm{~s})$, seemed less effective than medium concentrations from $40 \%$ to $60 \%$. This is in accordance with Donnell (2007) who stated that absolute ethanol is not a germicide because its action causes dehydration of microorganisms without killing them. Moreover, high concentration of alcohols leads to coagulation of the surface proteins. The biofilm is less fluid and reduces solvent penetration necessary for the elimination of microorganisms present in the deeper layer of the biofilm (Wilson et al. 1964). The optimum concentration of ethanol balances penetration with biocidal power, which is controlled by moisture content. Most studies of surface sterilization used $70 \%$ ethanol (Sponga et al. 1999, Schulz et al. 2008). However, our results showed that for macroalgal surface cleaning, $50 \%$ ethanol was more effective. This medium concentration is also a more gentle treatment on tissues, which is an important factor to take into account in macroalgal extraction studies. Moisture content values were similar to those described by Lüning (1990) and were also linked to treatment efficiency in our study. Mixed treatment using $40 \%$ ethanol with $1 \% \mathrm{NaOCl}$ for $60 \mathrm{~s}$ was effective on $F$. serratus. However, a greater concentration of ethanol $(50 \%)$ with $1 \% \mathrm{NaOCl}$ for $30 \mathrm{~s}$ was necessary for $P$. palmata. Moisture content determination showed that P. palmata has a water content higher than $84 \%$, compared with $80 \%$ in F. serratus. Consequently, ethanol may be diluted on the surface of P. palmata and thus a higher concentration of solvent was needed to remove the epibiotic microflora. U. lactuca and S. latissima had moisture contents $>80 \%$ and were treated with $50 \%$ ethanol with $1 \% \mathrm{NaOCl}$ for $30 \mathrm{~s}$; C. crispus with a $73 \%$ moisture content was better treated with $40 \%$ ethanol with $1 \% \mathrm{NaOCl}$ for 60 s. Higher concentrations of ethanol seem to be needed for macroalgae with higher water contents due to the dilution of the solvent on the surface. However, moisture content can vary due to environmental conditions such as weather or length of tidal exposure.

The biofilm on the surface of $P$. palmata was more removable than that on F. serratus. Controls and SEM images showed that fewer bacteria were growing on these macroalgae. Two hypotheses could explain the phenomenon: (i) macroalgal polysaccharides differ among Chlorophyceae, Phaeophyceae and Rhodophyceae, and surface chemistry may or may not provide a good environment for microbial growth (McCandless 1981); and (ii) antifouling (AF) molecules may prevent the development of a microflora (Hellio et al. 2001). Low abundances of microflora were observed on S. latissima, a species from which $\mathrm{AF}$ substances have been found previously (Carlsen et al. 2007). In Laminaria species, the process of sloughing the outer layer liberates the thallus from the developing epibiotic community (Lobban and Harrison 1994).

The present study demonstrated that macroalgal species (even in the same phylum) reacted differently to the surface sterilization methods employed. In summary, surface sterilization depends on biofilm and thus on environmental conditions as the level of microbial colonization increases in the spring, macroalgal species. It is also expected that it would vary with the polysaccharide constitution. To remove most microorganisms from macroalgal surfaces, the determination of the algal moisture content may help in choosing the best treatment. Species with moisture contents of $80 \%$ or more will be more effectively treated by $50 \%$ ethanol with $1 \%$ $\mathrm{NaOCl}$ for $30 \mathrm{~s}$ and those with contents of $<80 \%$ can be treated by $40 \%$ ethanol with $1 \% \mathrm{NaOCl}$ for $60 \mathrm{~s}$. Treatments should always be as short as possible; indeed, De Nys et al. (1998) showed that increased contact time between algal surface and concentrated solvent leads to a concomitant increase in secondary metabolite extraction.

Complete sterilization was not achieved with any of the procedures tested in this study and it seems unlikely that total removal of the microflora can be achieved without using a very aggressive method. The best protocol has to balance between the best removal possible and the lowest loss of molecules of interest during the process. The matrix effect of the "gel" protection phenomenon results from the nature of the biofilm itself (Sutherland 2001). EPSs contribute to the mechanical stability of biofilm (Mayer et al. 1999). They consist of $97 \%$ water and are relatively soluble in polar agents. However, the EPS backbone composition in addition to the presence of polyanions, due to uronic acid liberation (Sutherland 2001) and cations such as $\mathrm{Ca}^{2+}$ (Mack et al. 1996), control the rigidity of the biofilm by increasing the viscosity of the aqueous network (Loaec et al. 1997). This can limit penetration of biocides by the matrix effect and also interacts with biocidal agent by, for example, preventing radicals from causing oxidation. Absolute sterilization is therefore impossible.

This study highlighted methods for removing microorganisms associated with macroalgal surfaces and enhanced our understanding of disinfection of biological surfaces. The optimum treatment identified is based on a mixed treatment of ethanol and sodium hypochlorite. The two main issues that may rule out use of this treatment are (i) the potential loss of bioactive compounds during the process: this has been checked (data not shown) by measuring the level of bioactivity of the solvent wash, which was negative; and (ii) the potential loss of bioactive compounds during the process due to oxidative transformations; we did a preliminary check (data not shown) by measuring the bioactivity of $P$. palma acetone extracts with or without disinfection treatment (ethanol and sodium hypochlorite) and it appears that the bioactivity against adhesion of barnacle and mussel larvae was not affected, which is an indication that the chemical structures of the active compounds were not affected by the treatment. 
These results could be used in research on biofilms, bioactive molecules and sterilization. More testing should be carried out with a wider range of algal species. Other isolation and observation methods for microorganisms could be used to take into account a broad spectrum of organisms and not just those that are easily culturable. Other combinations of disinfection methods (combining physical and chemical methods) might also be investigated.

\section{References}

Aguirre-Lipperheide, M. and L.V. Evans. 1993. A sterilization protocol for the Dictyotales (Phaeophyceae) 1. J. Phycol. 29: 243-251.

Almeida, M.G., M. Humanes, R. Melo, J.A. Silva, J. da Silva and R. Wever. 2000. Purification and characterisation of vanadium haloperoxidases from the brown alga Pelvetia canaliculata. Phytochemistry 54: 5-11.

Anand, T.P., A.W. Bhata, Y.S. Shoucheb, U. Royb, J. Siddharthb and P.S. Siddhartha. 2006. Antimicrobial activity of marine bacteria associated with sponges from the waters off the coast of South East India. Microbiol. Res. 161: 252-262.

Armstrong, E., L.M. Yan, K.G. Boyd, P.C. Wright and J.G. Burgess. 2001. The symbiotic role of marine microbes on living surfaces. Hydrobiologia 461: 37-40.

Q3:

Pleas supply pp. for Atlas and Parks (1993), Atlas (2004), Colwell and Grimes (2000), De La Maza et al. (2004)
Atlas, R.M. 2004. Handbook of microbiological media. CRC Press, London.

Atlas, R.M. and L.C. Parks. 1993. Handbook of microbiological culture media. CRC Press, London.

Baker, J.T. 1984. Seaweeds in pharmaceutical studies and applications. Hydrobiologia 116-117: 29-40.

Baweja, P., D. Sahoo, P. García-Jiménez and R.R. Robaina. 2009. Seaweed tissue culture as applied to biotechnology: problems, achievements and prospects. Phycol. Res. 57: 45-58.

Bernan, V.S., M. Greenstein and W.M. Maiese. 1997. Marine microorganisms as a source of new natural products. Adv. Appl. Microbiol. 43: 57-90.

Blunt, J.W., B.R. Copp, W.P. Hu, M.H.G. Munro, P.T. Northcote and M.R. Prinsep. 2009. Marine natural products. Nat. Prod. Rep. 26: $170-244$.

Boyd, K.G., D.R. Adams and J.G. Burgess. 1999. Antibacterial and repellent activities of marine bacteria associated with algal surfaces. Biofouling 14: 227-236.

Bradley, P.M., D.P. Cheney and N. Saga. 1988. One step antibiotic disk method for obtaining axenic cultures of multicellular marine algae. Plant Cell Tiss. Org. Cult. 12: 55-60.

Callow, M.E., L.V. Evans, G.P. Bolwell and J.A. Callow. 1978. Fertilization in brown-algae. 1. SEM and other observations on Fucus serratus. J. Cell Sci. 32: 45-54.

Carlsen, B.P., G. Johnsen, J. Berge and P. Kuklinski. 2007. Biodiversity patterns of macro-epifauna on different lamina parts of Laminaria digitata and Saccharina latissima collected during spring and summer 2004 in Kongsfjorden, Svalbard. Polar Biol. 30: 939-943.

Characklis, W.G. and J.D. Bryers. 1981. Bioengineering report. Fouling biofilm development: a process analysis. Biotechnol. Bioeng. 23: 1923-1960.

Choi, J.S., J. Cho, L. Jin, H. Jin and Y. Hong. 2002. Procedures for the axenic isolation of conchocelis and monospores from the red seaweed Porphyra yezoensis. J. Appl. Phycol. 14: 115-121.
Clare, A.S. 1996. Natural product antifoulants: status and potential. Biofouling 9: 211-229.

Clare, A.S. 1998. Towards nontoxic antifouling. J. Mar. Biotechnol. 6: 3-6.

Colwell, R.R. and D.J. Grimes. 2000. Nonculturable microorganisms in the environment. American Society for Microbiology/ ASM Press, Washington, DC.

Costerton, J.W. 1999. Introduction to biofilm. Int. J. Antimicrob. Agents 11: 217-221.

Davey, M.E. and G.A. O'Toole. 2000. Microbial biofilms: from ecology to molecular genetics. Microbiol. Mol. Biol. Rev. 64: 847-867.

De La Maza, L.M., M.T. Pezzlo, J.T. Shigei and E. Peterson. 2004. Color atlas of medical bacteriology. American Society for Microbiology/ASM Press, Washington, DC.

De Nys, R., S.A. Dworjanyn and P.D. Steinberg. 1998. A new method for determining surface concentrations of marine natural products on seaweeds. Mar. Ecol. Prog. Ser. 162: 79-87.

Debashish, G., S. Malay, S. Barindra and M. Joydeep. 2005. Marine enzymes. Mar. Biotechnol. 96: 189-218.

Debeer, D., R. Srinivasan and P.S. Stewart. 1994. Direct measurement of chlorine penetration into biofilms during disinfection. Appl. Environ. Microbiol. 60: 4339-4344.

Decho, A.W. 2000. Microbial biofilms in intertidal systems: an overview. Cont. Shelf Res. 20: 1257-1273.

Donlan, R.M. 2002. Biofilms: microbial life on surfaces. Emerg. Infect. Dis. 8: 881-890.

Donnell, G.E.M. 2007. Antisepsis, disinfection and sterilization: types, action, and resistance. ASM Press, Washington, DC. pp. 361.

Faulkner, D.J. 2001. Marine natural products. Nat. Prod. Rep. 18: $1-49$.

Faulkner, J. 1993. Academic chemistry and the discovery of bioactive marine natural products. In: (D.H. Attaway and O.R. Zaborsky, eds) Marine biotechnology: pharmaceutical and bioactive natural products. Plenum Press, New York. pp. 459-470.

Fries, L. 1980. Axenic tissue cultures from the sporophytes of Laminaria digitata and Laminaria hyperborea (Phaeophyta). J. Phycol. 16: 475-477.

Fu, T., G. Singh and W.R. Curtis (eds). 1999. Plant cell and tissue culture for the production of food ingredients: an introduction. Division of Agricultural and Food Chemistry of the American Chemical Society. Kluwer Academic/Plenum Publishers, New York. pp. 296.

Fusetani, N. 2004. Biofouling and antifouling. Nat. Prod. Rep. 21: 94-104.

Garcia-Jiménez, P., M. Rodrigo and R.R. Robaina. 1998. Influence of plant growth regulators, polyamines and glycerol interaction on growth and morphogenesis of carposporelings of Grateloupia cultured in vitro. J. Appl. Phycol. 10: 95-100.

Gledhill, M., M.T. Brown, M. Nimmo, R. Moate and S.J. Hill. 1998. Comparison of techniques for the removal of particulate material from seaweed tissue. Mar. Environ. Res. 45: 295-307.

Guillard, R.R.L. and J.H. Ryther. 1962. Studies of marine planktonic diatoms. I. Cyclotella nana Hustedt and Detonula confervacea Cleve. Can. J. Microbiol. 8: 229-239.

Gusev, M.V., A.H. Tambiev, N.N. Kirikova, R.R. Aslanyan and N.N. Shelyastina. 1984. Obtaining of axenic explants from marine algae thallus. Izv. Acad. Nauk. USSR ser. Biol. 5: 716-721 (in Russian).

Gusev, M.V., A.H. Tambiev, N.N. Kirikovan, N.N. Shelyastina and R.R. Aslanyan. 1987. Callus formation in seven species of agarophyte marine algae. Mar. Biol. 95: 593-597. 
Haglund, A.L., E. Törnblom, B. Boström and L. Tranvik. 2002. Large differences in the fraction of active bacteria in plankton, sediments, and biofilm. Microb. Ecol. 43: 232-241.

Hall-Stoodley, L., J.W. Costerton and P. Stoodley. 2004. Bacterial biofilms: from the natural environment to infectious diseases. Nat. Rev. Microbiol. 2: 95-108.

Harder, T. 2009. Marine epibiosis: concepts, ecological consequences and host defence. In: (H.C. Flemming, P.S. Murthy, R. Venkatesan and K.E. Cooksey, eds) Marine and industrial biofouling (Springer Series on Biofilms). Springer-Verlag, Berlin/ Heidelberg. pp. 219-232.

Harrison, P.J. and J.A. Berges. 2005. Marine culture media. In: (R.A. Andersen, ed.) Algal culturing techniques. Elsevier Academic Press, London. pp. 21-34.

Haygood, M.G., E.W. Schmidt, S.K. Davidson and D.J. Faulkner. 1999. Microbial symbionts of marine invertebrates: opportunities for microbial biotechnology. J. Mol. Microbiol. Biotechnol. 1: 33-43.

Hellio, C., D. De La Broise, L. Dufosse, Y. Le Gal and N. Bourgougnon. 2001. Inhibition of marine bacteria by extracts of macroalgae: potential use for environmentally friendly antifouling paints. Mar. Environ. Res. 52: 231-247.

Hellio, C., J.P. Maréchal, B. Da Gama, R. Pereira and A.S. Clare. 2009. Natural marine products with antifouling activities. In: (C. Hellio and D. Yebra, eds) Advances in marine antifouling coatings and technologies. Woodshead Publishing, Cambridge. pp. 572-622.

Huang, L.N., H. De Wever and L. Diels. 2008. Diverse and distinct bacterial communities induced biofilm fouling in membrane bioreactors operated under different conditions. Environ. Sci. Technol. 42: 8360-8366.

Jensen, P.R. and W. Fenical. 1996. Marine bacterial diversity as a resource for novel microbial products. J. Ind. Microbiol. Biotechnol. 17: 346-351.

Jones, E.B.G. 2008. Bioactive compounds in marine organisms. Bot. Mar. 51: 161-162.

Jordan, P., B. Kloareg and H. Vilter. 1991. Detection of vanadatedependent bromoxidases in protoplasts from brown-algae Laminaria digitata and Laminaria saccharina. J. Plant Physiol. 137: 520-524.

Kawashima, Y. and H. Tokuda. 1993. Regeneration from callus of Undaria pinnatifida (Harvey) Suringar (Laminariales, Phaeophyta). Hydrobiologia 260-261: 385-389.

Kelecom, A. 2002. Secondary metabolites from marine microorganisms. An. Acad. Bras. Cienc. 74: 151-170.

Kohlmeyer, J. and B. Volkmann-Kohlmeyer. 2003. Marine ascomycetes from algae and animal hosts. Bot. Mar. 46: 285-306.

Lachnit, T., M. Blümel, J.F. Imhoff and M. Wahl. 2009. Specific epibacterial communities on macroalgae: phylogeny matters more than habitat. Aquat. Biol. 5: 181-186.

Lawlor, H.J., M.A. Borowitzka and J.A. McComb. 1991. A rapid and inexpensive method for surface sterilisation of Ecklonia radiata (Phaeophyta) for tissue culture. Bot. Mar. 34: 261-264.

Leblanc, C., C. Colin, A. Cosse, L. Delage, S. La Barre, P. Morin, B. Fiévet, C. Voiseux, Y. Ambroise, E. Verhaeghe, D. Amouroux, O. Donard, E. Tessier and P. Potin. 2006. Iodine transfers in the coastal marine environment: the key role of brown algae and of their vanadium-dependent haloperoxidases. Biochimie 88 : $1773-1785$.

Loaec, M., R. Olier and J. Guezennec. 1997. Uptake of lead, cadmium and zinc by a novel bacterial exopolysaccharide. Water Res. 31: 1171-1179.

Lobban, C.S. and P.J. Harrison. 1994. Seaweed ecology and physiology. Cambridge University Press, Cambridge. pp. 366.
Lüning, K. 1990. Seaweeds: their environment, biogeography and ecophysiology. John Wiley \& Sons Press, New York. pp. 527.

Mack, D., W. Fischer, A. Krokotsch, K. Leopold, R. Hartmann, H. Egge and R. Laufs. 1996. The intercellular adhesin involved in biofilm accumulation of Staphylococcus epidermidis is a linear beta-1,6-linked glucosaminoglycan: purification and structural analysis. J. Bacteriol. 178: 175-183.

Mayer, C., R. Moritz, C. Kirschner, W. Borchard, R. Maibaum, J. Wingender and H.C. Flemming. 1999. The role of intermolecular interactions: studies on model systems for bacterial biofilms. Int. J. Biol. Macromol. 26: 3-16.

Mayer, A.M.S., A.D. Rodríguez, R.G.S. Berlinck and M.T. Hamannd. 2009. Marine pharmacology in 2005-6: marine compounds with anthelmintic, antibacterial, anticoagulant, antifungal, anti-inflammatory, antimalarial, antiprotozoal, antituberculosis, and antiviral activities; affecting the cardiovascular, immune and nervous systems, and other miscellaneous mechanisms of action. Biochim. Biophys. Acta 1790: 283-308.

McCandless, 1981. Polysaccharides of seaweeds. In: (C.S. Lobban and M.J. Wynne, eds) The biology of seaweeds. Botanical monograph. Vol. 17. University of California Press, Berkeley/Los Angeles, CA. pp. 559-588.

Mérour, J.Y. 2004. La mer, source de molécules bioactives. Sciences 3: $15-22$.

Molinski, T.F., D.S. Dalisay, S.L. Lievens and J.P. Saludes. 2009. Drug development from marine natural products. Nat. Rev. Drug Discov. 8: 69-85.

Nye, K.J., D. Fallon, D. Frodsham, B. Gee, C. Graham, S. Howe, S. Messer, T. Turner and R.E. Warren. 2002. An evaluation of the performance of XLD, DCA, MLCB, and ABC agars as direct plating media for the isolation of Salmonella enterica from faeces. J. Clin. Pathol. 55: 286-288.

Okami, Y. 1986. Marine microorganisms as a source of bioactive agents. Microb. Ecol. 12: 65-78.

Paul, V.J. and M.P. Puglisi. 2004. Chemical mediation of interactions among marine organisms. Nat. Prod. Rep. 21: 189-209.

Prieur, D., F. Gaill and S. Corre. 1993. Complex epibiotic bacterial communities on marine organisms: fouling or interactions? Trends Microbial. Ecol. 207-212.

Proksch, P., R. Edrada and R. Ebel. 2002. Drugs from the seas current status and microbiological implications. Appl. Microbiol. Biotechnol. 59: 125-134.

Qian, P.Y., S.C.K. Lau, H.U. Dahms, S. Dobretsov and T. Harder. 2007. Marine biofilms as mediators of colonization by marine macroorganisms: implications for antifouling and aquaculture. Mar. Biotechnol. 9: 399-410.

Ralston, E. and G. Swain. 2009. Bioinspiration - the solution for biofouling control? Bioinspir. Biomimet. 4: 1-9.

Reddy, C.R.K., B. Jha, Y. Fujita and M. Ohno. 2008. Seaweed micropropagation techniques and their potentials: an overview. J. Appl. Phycol. 20: 609-617.

Renn, D.W. 1990. Seaweeds and biotechnology - inseparable companions. Hydrobiologia 204-205: 7-13.

Rorrer, G.L. and D.P. Cheney. 2004. Bioprocess engineering of cell and tissue cultures for marine seaweeds. Aquacult. Eng. 32: $11-41$.

Rosell, K.G. and L.M. Srivastava. 1987. Fatty acids as antimicrobial substances in brown-algae. Hydrobiologia 151: 471-475.

Scardino, A.J., D. Hudleston, Z. Peng, N.A. Paul and R. de Nys. 2009. Biomimetic characterisation of key surface parameters for the development of fouling resistant materials. Biofouling 25: 83-93.

Schulz, B., S. Guske, U. Dammann and C. Boyle. 1998. Endophyte-

Q4:
Please
supply
initials for
McCandless
in
McCandless
$(1981)$

Q5: Please supply the volume number for Prieur et al. (1993) 
host interactions. II. Defining symbiosis of the endophyte-host interaction. Symbiosis 25: 213-227.

Schulz, B., S. Draeger, T.E. de la Cruz, J. Rheinheimer, K. Siems, S. Loesgen, J. Bitzer, O. Schloerke, A. Zeeck, I. Kock, H. Hussain, J.Q. Dai and K. Krohn. 2008. Screening strategies for obtaining novel, biologically active, fungal secondary metabolites from marine habitats. Bot. Mar. 51: 219-234.

Sieburth, J.M.N. 1969. Studies on algal substances in the sea. III. The production of extracellular organic matter by littoral marine algae. J. Exp. Mar. Biol. Ecol. 3: 290-309.

Sponga, F., L. Cavaletti, A. Lazzarini, A. Borghi, I. Ciciliato, D. Losi and F. Marinelli. 1999. Biodiversity and potentials of marine-derived microorganisms. J. Biotechnol. 70: 65-69.

Steinberg, P.D. and R. De Nys. 2002. Chemical mediation of colonization of seaweed surfaces. J. Phycol. 38: 621-629.

Steinberg, P.D., R. De Nys and S. Kjelleberg. 2002. Chemical cues for surface colonization. J. Chem. Ecol. 28: 1935-1951.

Stoodley, P., K. Sauer, D.G. Davies and J.W. Costerton. 2002. Biofilms as complex differentiated communities. Annu. Rev. Microbiol. 56: 187-209.

Sutherland, I.W. 2001. Biofilm exopolysaccharides: a strong and sticky framework. Microbiology 147: 3-9.

Vilter, H., K.W. Glombitza and A. Grawe. 1983. Peroxidases from Phaeophyceae. 1. Extraction and detection of the peroxidases. Bot. Mar. 26: 331-339.

Wahl, M. 1989. Marine epibiosis. I. Fouling and antifouling: some basic aspects. Mar. Ecol. Prog. Ser. 58: 175-189.
Wahl, M. 2008. Ecological lever and interface ecology: epibiosis modulates the interactions between host and environment. Biofouling 24: 427-438.

Wahl, M., K. Kroeger and M. Lenz. 1998. Non-toxic protection against epibiosis. Biofouling 12: 1-3.

Wilson, T.A., S. Graham, A. Miles, A. Knox, R. Parker, M.T. Macrae, A.D. Meynell, G.G. Meynell, W. Elinor. 1964. Topley and Wilson's principles of bacteriology and immunity. Edward Arnold, London. pp. 1964.

Xuewu, L. and B. Kloareg. 1992. Explant axenisation for tissue culture in marine macroalgae. Chin. J. Oceanol. Limnol. 10: $268-275$.

Xue-wu, L. and M.E. Gordon. 1987. Tissue and cell culture of New Zealand Pterocladia and Porphyra species. Hydrobiologia 151-152: 147-154.

Zheng, L., X.T. Han, H.M. Chen, W. Lin and X.J. Yan. 2005. Marine bacteria associated with marine macroorganisms: the potential antimicrobial resources. Ann. Microbiol. 55: 119-124.

Zobell, C.E. 1941. Studies on marine bacteria. I. The cultural requirements of heterotrophic aerobes. J. Mar. Res. 4: 42-75.

Zuccaro, A., C.L. Schoch, J.W. Spatafora, J. Kohlmeyer, S. Draeger and J.I. Mitchel. 2007. Detection and identification of fungi intimately associated with the brown seaweed Fucus serratus. Appl. Environ. Microbiol. 74: 931-941.

Received 2 February, 2011; accepted 28 July, 2011 